Revista do Corpo Discente do Programa de Pós-Graduação em História da UnB

Em TEMPO DE HIStóRIAS | Brasília-DF | n. 36 | p. 66-80 | jan./jun. 2020.

ISSN 2316-1191

This work is licensed under a Creative Commons Attribution-NonCommercial 4.0 International License.

Recebido em 23/05/2020

Aceito em 20/06/2020

DOI: $10.26512 /$ emtempos.v1i36.31728

\title{
DOSSIE
}

\section{A política da morte nos projetos abolicionistas de Andrade Corvo e Joaquim Nabuco}

\author{
The death policy in the abolitionist projects \\ of Andrade Corvo and Joaquim Nabuco
}

\author{
Gabriel Felipe Silva Bem \\ Doutorando em História na UFMG \\ gabriel.f.bem@hotmail.com
}

\begin{abstract}
RESUMO: O presente artigo tem como principal objetivo construir uma história interligada entre o pensamento de dois autores abolicionistas do século XIX: João de Andrade Corvo, por meio da análise da obra Estudos sobre as provincias ultramarinas (1883-1887), e Joaquim Nabuco, com o livro O Abolicionismo (1883), sendo o primeiro português e o segundo brasileiro. $\mathrm{O}$ eixo norteador da análise é o conceito de necropolítica do autor Achille Mbembe. Tentou-se comprovar que os projetos abolicionistas dos dois autores carregavam um ideal colonial que mobilizava a necropolítica, na medida que planejaram a eliminação de indivíduos negros em prol de uma idealização de sociedade ideal.
\end{abstract}

PALAVRAS-CHAVE: Abolicionismo; Colonização; Escravidão.

ABSTRACT: The present article has as main objective to build a history interconnected between the thoughts of two 19th century abolitionist authors: João de Andrade Corvo, through the analysis of the Estudos sobre as provincias ultramarinas (1883-1887), and Joaquim Nabuco, with the book $O$ Abolicionismo (1883), the first was Portuguese and the second Brazilian. The guiding axis of the analysis is the concept of necropolitics by the author Achille Mbembe. We tried to prove that the abolitionist projects of the two authors carried a colonial ideal that mobilizes the necropolitics, insofar as they planned to eliminate black individuals in favor of an idealization of an ideal society.

KEYWORDS: Abolitionism; Colonization; Slavery. 
Revista do Corpo Discente do Programa de Pós-Graduação em História da UnB

EM TEMPO DE HISTÓRIAS | Brasília-DF | n. 36 | p. 66-80 | jan./jun. 2020.

ISSN 2316-1191

\title{
Introdução
}

No livro que é talvez a obra mais influente do abolicionismo brasileiro, Joaquim Nabuco escreveu o seguinte:

\begin{abstract}
Quem chega ao Brasil e abre um dos nossos jornais encontra logo uma fotografia da escravidão atual, mais verdadeira do que qualquer pintura. Se o Brasil fosse destruído por um cataclismo, um só número, ao acaso, de qualquer dos grandes órgãos da Imprensa, bastaria para conservar para sempre as feições e os caracteres da escravidão, tal qual existe em nosso tempo. Não seriam precisos outros documentos para o historiador restaurá-la em toda a sua estrutura e segui-la em todas as suas influências. (NABUCO, 2003, p,105)
\end{abstract}

Para o bem ou para o mal o trabalho do historiador dos dias de hoje não é tão fácil como Nabuco previu, mas ele acertou no que diz respeito à intencionalidade retórica do trecho. Para ele, a escravidão era algo tão central na sociedade brasileira que poderia facilmente ser achada em qualquer edição de jornal. O problema é que exatamente por causa dessa centralidade e amplitude que se faz necessário que o historiador contemporâneo pesquise em diferentes fontes e em diferentes espaços. Dessa forma é possível construir um quadro mais completo do que foi a escravidão no Brasil e no mundo.

A escravidão do século XIX aconteceu em um mundo de mercados capitalistas interligados: com intensas trocas comerciais e culturais, além de uma política diplomática pujante. $\mathrm{O}$ que acontecia no Brasil em relação a escravidão, que era a principal força produtiva do país, podia influenciar em outros espaços, assim como acontecimentos no mundo todo influenciavam a política e os debates no Brasil. Se quisermos ter uma visão mais completa do que era a política escravista no Brasil, se faz necessário uma visão interligada, conectando vários centros de poder.

Uma perspectiva de história interligada na realidade não é uma grande novidade, vários campos e perspectivas já preveem ações metodológicas nesse sentido, como é o caso da História Atlântica e da História Global. A perspectiva interligada pretende ir além das comparações entre semelhanças e diferenças, apesar de essas não serem totalmente excluídas, e analisar o desenvolvimento de maneira globalmente conectado a partir de estruturas que estão mutuamente se influenciando.

Estudos recentes têm explorado essa linha de história interligada, como o de Tâmis Parron (2015) e de Alain El Youssef (2019). Diferentemente desses estudos, que buscaram fazer uma interligação entre relações comerciais ou diplomáticas de espaços escravista ou antiescravista, busco entender uma relação discursiva que aproximava dois influentes abolicionistas do século XIX, Joaquim Nabuco e Andrade Corvo. Ambos ocuparam cargos políticos em seus governos, respectivamente Brasil e Portugal, e elaboraram projetos abolicionistas que têm como base um discurso colonialista.

Tomando como referência os estudos de Said (2016) e de Mudimbe (2013), entendo que o colonialismo não é apenas uma prática material de domínio de territórios estrangeiros e de eliminação ou exploração física dos habitantes autóctones, mas também uma prática discursiva, que através de um arcabouço teórico refinado buscou legitimar as ações do colonialismo. Discurso aqui é entendido como a 
Revista do Corpo Discente do Programa de Pós-Graduação em História da UnB

Em TEMPO DE HISTÓRIAS | Brasília-DF | n. 36 | p. 66-80 | jan./jun. 2020.

ISSN 2316-1191

materialização do ideológico e do linguístico, sendo que tomo como base os estudos de Foucault (1971), que entende o discurso como uma família de enunciados pertencentes a uma mesma formação discursiva, ou seja, a uma mesma ordem.

O que tento demonstrar com este artigo é que os discursos de Nabuco e Corvo seguiam uma mesma base epistemológica, sendo que essa ordem era fruto do discurso colonial. Esse passava por uma visão racializada com uma tendência civilizadora, que, em outras palavras, significava a eliminação física e cultural de indivíduos considerados racialmente inferiores, que aqui se referem principalmente a africanos e seus descendentes no Brasil, para a implementação da cultura europeia. Ambos dos autores, de maneira diferente, convergiram para uma política de morte, algo que cabe dentro do termo de Achille Mbembe (2018) de "necropolítica".

Mbembe se apoia no conceito foucaultiano de "biopoder", mas entende que esse é insuficiente para definir as formas contemporâneas de soberania. Para ele a expressão máxima da soberania é a necropolítica ou necropoder, que é quando o controle dos corpos se exerce por meio do poder de matar. $\mathrm{O}$ conceito de Mbembe não se restringem às políticas de extermínios e eliminação física ostensiva. A condição de necropolítica também é criada em situações em que existe uma negação estrutural do direito à vida, existindo, dessa forma, um abismo entre os indivíduos submetidos a esse sistema e a humanidade plena. Os sujeitos são considerados sombras do ideal de homem ou mulher e podem ser facilmente reduzidos a situação de morte. Por esse motivo creio que o conceito de necropolítica é ideal para definir a política abolicionista de Corvo e Nabuco. Os motivos serão detalhados nos próximos tópicos, mas antes de fazer uma relação entre os autores, acredito ser importante uma breve análise da biografia e da obra de cada um, o que nos ajudará a entender o lugar e as intencionalidades por trás dos discursos.

\section{Andrade Corvo e a extinção das "raças inferiores"}

João de Andrade Corvo (1824-1890) era um intelectual e agrônomo, sendo o nome forte nas questões internacionais e coloniais de Portugal durante o governo conhecido como Fontismo. ${ }^{1}$ Nesse período, ele foi Ministro dos Negócios Estrangeiros entre 1871 e 1878, pasta que acumulou com o Ministério da Marinha e Ultramar. Ele se colocava como herdeiro de uma política antiescravista iniciada por outro importante Ministro da Marinha e do Ultramar, Marquês de Sá da Bandeira. Foi Corvo que aboliu a condição de liberto em 1876, ${ }^{2}$ consolidando a legislação abolicionista no Império

\footnotetext{
${ }^{1}$ Fontismo foi como ficou conhecido o Governo Português das décadas de 1870 e 1880 sobre a liderança de António Maria de Fontes Pereira de Melo, que ficou marcado pelas tentativas de modernização da infraestrutura do país.

2 A condição de liberto foi criada pelo Estatuto do Liberto, que deveria ser uma etapa intermediária entre a escravidão e o trabalho livre. O ex-escravo durante sete ou dez anos deveria aprender o trabalho livre com o seu antigo senhor, que seria chamado de tutor. Na prática, esse estatuto só mudou o nome da escravidão, mas a condição continuou a mesma, vigorando até um comércio de libertos análogo ao de escravos.
} 
Revista do Corpo Discente do Programa de Pós-Graduação em História da UnB

Em TEMPO DE HISTÓRIAS | Brasília-DF | n. 36 | p. 66-80 | jan./jun. 2020.

ISSN 2316-1191

Português. O livro que foi estudado para este trabalho é o Estudos sobre as Provincias Ultramarinas, publicado em quatro volumes, entre 1883 e 1887. Trata-se de um balanço do que foi o governo dele, em que foram detalhados os projetos coloniais e suas motivações políticas.

Andrade Corvo era uma figura interessante e com ideias singulares, muito embora talvez fosse o típico estereótipo de intelectual do século XIX. Interessava-se por literatura e poesia, fascinava-se pelas principais descobertas da ciência, gostava de ler relatos de viagens, opinava e se mostrava inteirado sobre as grandes questões políticas da Europa, teve passagem em um cargo importante do seu governo e era racista. Sendo que promoveu e implementou políticas que eram baseadas em teorias raciais. O que estou chamando de "teorias raciais" são os argumentos de base científicas centrados em grupos que eram entendidos como resultado de uma estrutura biológica singular e que produziu diferenciação e hierarquização de sociedades humanas (SCHWARCZ, 1993). Corvo também era um liberal, atuou na quebra de monopólios e promoveu obras de viação, sendo que, como bom liberal do século XIX, acreditava que a abolição da escravidão era condição primeira para o desenvolvimento das colônias africanas e por isso fez de tudo para promovê-la.

A grande questão é que apenas a abolição não bastaria. Corvo acreditava que era necessário regenerar o negro embrutecido pela escravidão, em outras palavras, civilizá-lo. Essa seria a única saída para o desenvolvimento da África. As palavras deles são as seguintes:

E pois da civilisação e da actividade dos indigenas que tudo ha a esperar. Às idéas que se faziam da raça negra, no tempo da escravidão, estão longe de ser verdadeiras. O negro é susceptível de aperfeiçoamento, de illustração, de actividade, de industria. Ha diversas raças, umas mais intelligentes do que outras, umas em que a evolução das faculdades mentaes attingiu um grau mais elevado do que em outras. A escravidão embruteceu o negro, e fez-lhe perder o grande incentivo do trabalho; o interesse próprio. (CORVO, 1883, p. 272).

Corvo era um legítimo colonialista, ele encarnava a missão civilizadora, sendo que pensava e praticava uma série de políticas que ele acreditava que levariam até ela. Nesse sentido ele usou as teorias raciais, evidentes no trecho acima, como ferramenta analítica das sociedades africanas, algo que o ajudaria a completar sua missão na colonização.

O interessante é que Corvo se entendia como um homem da ciência, como um homem racional, e a política portuguesa de colonização deveria seguir esse mesmo caminho da razão. O tempo do fanatismo religioso, com os jesuítas, e das políticas nefastas, como a escravidão e monopólios, deveria ficar para trás. A nova política colonial era racional e civilizada, como ele deixou claro no seguinte trecho, em que discutia a necessidade da criação de caminhos de ferros nas colônias:

A escravidão acabou: o trabalho, auxiliado pelas maravilhas da sciencia moderna, é o melhor, o mais seguro meio de civilisar povos selvagens, ou semiselvagens; a riqueza, conquistada pela liberdade, é tudo: a instrucção deve derramar-se por toda a parte com mãos largas, como um dever moral e como uma boa especulação social; as manifestações do poder do homem sobre a 
Revista do Corpo Discente do Programa de Pós-Graduação em História da UnB

Em TEMPO DE HISTÓRIAS | Brasília-DF | n. 36 | p. 66-80 | jan./jun. 2020.

ISSN 2316-1191

natureza são o mais seguro meio de subjugar as paixões desregradas dos bárbaros; as riquezas, creadas pela mão do homem, são a arma mais forte para vencer resistências, e abrir o caminho ás verdadeiras conquistas. A razão tem mais poder do que a espada. A harmonia tem mais influencia do que a força. A energia creadora é mais irresistível do que a energia que destroe. (CORVO, 1883, p. 252-253).

As teorias raciais entraram nesse contexto de valorização da ciência e da razão. Essas teorias, que na grande maioria das vezes pregavam a superioridade europeia, foram usadas durante todo o processo colonizador do século XIX e XX para minimizar, inferiorizar, excluir e destruir culturas não europeias, além de servir como justificativa de políticas genocidas em vários lugares e épocas.

Andrade Corvo não falava abertamente sobre uma política de extermínio, mas isso não quer dizer que a morte não estava na sua política colonial pós-abolição. Ele acreditava que alguns grupos étnicos da África seriam tão intelectualmente inferiores que simplesmente entrariam em extinção com a chegada da civilização. Corvo apresentava um determinismo racial guiado por uma leitura de Darwin que parece enviesada pela visão de Spencer da "sobrevivência do mais apto" (POLIAKOV, 1971, p. 282 - 298), apesar de ele não citar esse autor. Dessa maneira, alguns grupos estavam condenados à extinção. É perturbador perceber que Corvo enxergava a civilização como uma força capaz de provocar a extinção de seres humanos que não se adaptassem a ela. As palavras dele são as seguintes:

A escravidão é, em nossa opinião, a principal causa do grande atrazo de todo o género, em que se acham ainda as populações indígenas da Africa; quando todos os povos progridem, ou, se não podem resistir á acção da civilisação e adaptar-se a ela, se extinguem com deplorável rapidez. Vemos, em diversas partes do mundo, os povos selvagens fugirem diante da civilisação, e por fim extinguirem-se. Verdade ê, que o espirito cubiçoso e brutal dos colonos europeus tem contribuído muito para isso; mas, é certo também, que parece haver alli a acção de uma lei mysteriosa e fatal, a qual condemna á destruição as raças inferiores, que não teem responsabilidade e não podem amoldar-se ao systema que lucta pela existência; systema social que consiste em tomar, por assim dizer, posse das forças da natureza, e usar d'essas forças em serviço próprio. Ha aqui alguma coisa d'aquella lei de Darwin: "Pode dizer-se, metaphoricamente, que a selecção natural está a cada instante buscando no mundo as mais insignificantes variações, rejeitando as que são más, preservando e accrescentando as que são boas; silenciosamente e insensivelmente trabalhando, cada vez que a occasião se offerece, no melhoramento de cada ser organico; em relação ás suas condições de vida, quer orgânicas, quer inorgânicas.” As formas que não prestam extinguem-se; as outras desenvolvem-se e progridem. Na Africa encontramos também raças que evidentemente tendem a extinguirse; mas ha muitas outras, que parece quererem desenvolver se e progredir. (CORVO, 1885, p. 55-56).

Vale ressaltar que civilização para Corvo nada mais é que uma série de costumes e ações que remetiam a cultura europeia, então alguém só poderia ser civilizado caso se parecesse com um Europeu. O que é característico desse discurso do Corvo é a estratégia retórica de "apassivamento linguístico" da necropolítica colonial. Em vez de enunciar que "a civilização (colonialismo) mata algumas populações" como verbo transitivo matar (que pressupõe um sujeito e um objeto da ação), ele invoca o 
Revista do Corpo Discente do Programa de Pós-Graduação em História da UnB

Em TEMPO DE HISTÓRIAS | Brasília-DF | n. 36 | p. 66-80 | jan./jun. 2020.

ISSN 2316-1191

verbo intransitivo "extinguir-se", eliminando o sujeito da ação. O sujeito, em vez de ser o colonizador, que mata, torna-se o colonizado, que "se extingue" sozinho.

Para Corvo o africano estava tão atrofiado pela raça e brutalizado pela escravidão que seria necessários séculos de preparação para a chegada da civilização no continente. Ele deixou isso evidente em várias passagens da sua obra. Um exemplo é quando ele discutiu a influência da evangelização cristã na colonização, ele faz o seguinte apontamento:

Não se julgue de quanto fica dito, que desconhecemos a importância da propaganda religiosa na Africa. Julgamos, ao contrario, que a benéfica influencia da moral christã deve exercer a mais pura e mais civilisadora acção no espirito d'aquelles povos; que a queda da idolatria e o desaparecimento do fanatismo e das suas praticas barbaras, ferozes muitas vezes, necessariamente hão de preceder a completa transformação social dos negros. O que, porém, não julgamos possível é que, no cérebro por assim dizer incompleto do africano, possam, sem longa preparação, sem um longo e prévio trabalho de educação moral e physica, entrar outras idéas, para receber as quaes o selvagem não está preparado, e que necessariamente repugnam á sua índole brutal. (CORVO, 1885, p. 119-120).

Nas palavras do próprio Corvo: "Os negros são como as creanças, que houvessem parado no seu desenvolvimento mental; tem as paixões, a insensibilidade, o fogo, a falta de madureza, e a preguiça para o trabalho, que nas creanças se observa." (CORVO, 1885, p. 144). Caberia então aos europeus a "difficil empreza de civilisar o negro" (CORVO, 1885, p. 144). Mas como isso se daria? Para Corvo essa resposta era óbvia e só existiria um caminho, o do trabalho. O grande projeto de Corvo para a civilização compreende domar o instinto natural dos negros, que ele julgava existir, e aplicá-lo através do trabalho na viabilização da exploração econômica das colônias. Dessa forma, os instintos naturais seriam aplicados na civilização.

Pode parecer um contrassenso querer regenerar pessoas brutalizadas pelo trabalho exploratório com mais trabalho, mas para ele não era. A natureza do trabalho seria diferente, o trabalho que ele tentava promover não era esterilizante, mas sim edificante, sendo que seria baseado em um senso de justiça, instrução e liberdade. Pelo menos era assim que ele acreditava. Na conclusão do terceiro volume da sua obra, ele resumiu a política civilizacional dos "indígenas" da seguinte forma:

Ensinar os negros a serem úteis, a comprehenderem as vantagens do trabalho, e os benefícios do commercio: crear nos negros as necessidades, que representam melhoramento na vida material, desenvolvimento na vida moral: abrir aos negros horizontes, por onde se possam expandir as suas limitadas aptidões, a fim de lhes transformar a natural indolência em actividade productiva: ensinar os negros pelo exemplo, atrail-os pela benevolência, domarlhes as ruins paixões pela justiça, impressional-os pelas maravilhas da civilisação, ministrar lhes na escola e na officina, um ensinamento que os persuada de que elles podem seguir as praticas dos brancos, com vantagem própria: eis o que temos a fazer na Africa portugueza. (CORVO, 1884 p. 389).

$\mathrm{O}$ que se pode ver de maneira muito intensa na obra de Andrade Corvo é a presença do liberalismo, isso fica evidente na maneira como ele defende os benefícios 
Revista do Corpo Discente do Programa de Pós-Graduação em História da UnB

Em TEMPO DE HISTÓRIAS | Brasília-DF | n. 36 | p. 66-80 | jan./jun. 2020.

ISSN 2316-1191

do comércio e a necessidade de melhoramento da vida material, é isso que explica também sua defesa do trabalho livre como a melhor ferramenta de colonização.

A teoria clássica do liberalismo, da qual um dos grandes autores foi Adam Smith (1723-1790), deu uma importante contribuição para a causa do abolicionismo, já que entendia a escravidão como improdutiva e não natural. Considerando que a livre iniciativa privada e a busca pelo interesse pessoal eram naturais e promoviam o bem público, Smith criticou toda a rede de monopólios e privilégios que de alguma maneira desarmonizam ou impediam o impulso natural da busca individual por melhores condições de vida, entre eles a escravidão. Segundo ele, o escravo estava impedido pelas condições do cativeiro de obter propriedade ou de empreender riquezas livremente; com isso, ele não teria incentivo para o trabalho, fazendo sempre o mínimo possível. Para Smith, os proprietários de terras lucrariam mais se simplesmente dividissem parte da sua produção com os trabalhadores na forma de salário, incentivando assim a produtividade (SMITH, 1996).

Outro autor relevante e que conviveu diretamente com Smith foi John Millar (1735-1801), para quem as relações de propriedade eram a chave dos vários estágios da evolução social. Todas as instituições que regulavam a autoridade estavam relacionadas com a propriedade privada, como a atividade econômica, a autoridade dos pais, a posição da mulher, a organização social, as leis, os costumes e o uso do lazer. Para ele, devido ao fato de que a escravidão era um sistema que não incentivava a busca pela propriedade privada, não podia ser considerada econômica. A conclusão dessa visão liberal sobre trabalho e salário é a de que a escravidão é a forma mais cara e menos produtiva de trabalho, sendo que só continuava viva por causa da cegueira dos grandes senhores de escravos (DAVIS, 2001, p. 469 - 491).

O projeto colonial de Andrade Corvo nada mais é do que estabelecer uma ordem liberal nas colônias, era isso que ele entendia por civilização. Nessa nova ordem não cabia mais a escravidão. Mas o que aconteceria com as pessoas que não se adaptassem a civilização? A resposta já foi dada em uma das transcrições acima, se extinguiriam, em outras palavras, seriam exterminadas pela força da civilização. Um extermínio tão natural quanto o de um animal que não se adapta a um novo ambiente. Pelo menos é dessa forma que Corvo formula, de maneira passiva. Apesar disso, devemos nos atentar ao fato de que a civilização deveria ser promovida pelos portugueses, então seriam eles que promoveriam a morte. O projeto colonial de Corvo, assim como quase todos, era um projeto de necropolítica.

O colonialismo era uma força tão predominante no século XIX que se proliferou por todo o mundo. Elites de diferentes locais absorviam os ideais colonialistas e tentavam adaptar a sua realidade nacional. No Brasil não foi diferente, o discurso colonial também penetrou nas camadas abolicionistas e criou discurso como o de Joaquim Nabuco. 
Revista do Corpo Discente do Programa de Pós-Graduação em História da UnB

Em TEMPO DE HISTÓRIAS | Brasília-DF | n. 36 | p. 66-80 | jan./jun. 2020.

ISSN 2316-1191

\section{Nabuco e a eliminação do negro pela miscigenação}

Joaquim Aurélio Barreto Nabuco de Araújo (1849-1910) é um dos mais conhecidos abolicionistas brasileiros, seja pela sua importância no movimento, seja pela quantidade de material escrito que ele deixou. Nabuco era membro da elite tradicional brasileira, seu pai, José Tomás Nabuco de Araújo Filho (1813-1878), foi senador do Império e seu avô, José Tomás Nabuco de Araújo (1775-1850), também. Não surpreende que Joaquim Nabuco, que recebeu a melhor educação ilustrada que a posição do seu pai podia garantir, seguisse o caminho dos seus antepassados ingressando na Câmara dos Deputados em 1878.

Apesar de uma atuação relevante como político, Nabuco é mais conhecido como articulador e propagador de ideias e associações abolicionistas. Além de ter entrado para o cânone brasileiro como "herói da abolição". Chega até a surpreender a longa duração da canonização de Nabuco, sendo que alguns historiadores recentes se esforçam para defender sua biografia como uma espécie de intelectual a frente do seu tempo. Apesar disso, novas perspectivas têm aparecido para humanizar a figura de Nabuco, apresentando-o com um individuo do seu tempo e destacando, por exemplo, a presença das teorias raciais no seu trabalho (AZEVEDO, 2001). Algo que pretendo fazer neste artigo

O livro de Nabuco que vou analisar é o já mencionado O Abolicionismo, publicado pela primeira vez em 1883. O trabalho é um esforço de propaganda abolicionista, mas vai muito além de um caráter panfletário e contém uma análise ampla da sociedade brasileira, das legislações abolicionistas até então existentes e uma projeção de futuro. O livro gira em torno da ideia de que o escravismo não era só uma força de trabalho, mas também uma espécie de força metafísica que tudo corromperia e atrofiava. Por causa disso que o governo, o comércio, o trabalho, todas as classes sociais, a indústria, a lavoura e a sociedade brasileira como um todo estavam condenados ao atraso e ao subdesenvolvimento. Nabuco lista os motivos pelos quais ele era contra o escravismo no seguinte trecho:

Mas os fundamentos do abolicionismo não se reduzem às promessas falsificadas na execução, aos compromissos nacionais repudiados, nem ao sentimento de honra do país compreendida como a necessidade moral de cumprir os seus tratados e as suas leis com relação à liberdade e de conformar-se com a civilização no que ela tem de mais absoluto. Além de tudo isso, e da ilegalidade insanável da escravidão perante o direito social moderno e a lei positiva brasileira, o abolicionismo funda-se nume série de motivos políticos, econômicos, sociais e nacionais, da mais vasta esfera e do maior alcance. Nós não queremos acabar com a escravidão somente porque ela é ilegítima em face do progresso das ideias morais de cooperação e solidariedade; porque é ilegal em face da nossa legislação do período do tráfico; porque é uma violação da fé pública, expressa em tratados como a convenção de 1826, em leis como a de 7 de novembro, em empenhos solenes como a carta de Martim Francisco, a iniciativa do conde d'Eu no Paraguai, e as promessas dos estadistas responsáveis pela marcha dos negócios públicos.

Queremos acabar com a escravidão por esses motivos seguramente, e mais pelos seguintes: 


\section{Filistorias}

Revista do Corpo Discente do Programa de Pós-Graduação em História da UnB

Em TEMPO DE HISTÓRIAS | Brasília-DF | n. 36 | p. 66-80 | jan./jun. 2020.

ISSN 2316-1191

1. Porque a escravidão arruina economicamente o país, impossibilita o seu progresso material, corrompe-lhe o caráter, desmoraliza-lhe os elementos constitutivos, tira-lhe a energia e a resolução, rebaixa a política; habitua-o ao servilismo, impede a imigração, desonra o trabalho manual, retarda a aparição das indústrias, promove a bancarrota, desvia os capitães do seu curso natural, afasta as máquinas, excita o ódio entre classes, produz uma aparência ilusória de ordem, bem estar e riqueza, a qual encobre os abismos de anarquia moral, de miséria e destituição, que do Norte ao Sul margeiam todo o nosso futuro.

2. Porque a escravidão é um peso enorme que atrasa o Brasil no seu crescimento em comparação com os outros Estados sul-americanos que a não conhecem; porque, a continuar, esse regime há de forçosamente dar em resultado o desmembramento e a ruína do país; porque a conta dos seus prejuízos e lucros cessantes reduz a nada o seu apregoado ativo, e importa em uma perda nacional enorme e contínua; porque, somente quando a escravidão houver sido de todo abolida, começará a vida normal do povo, existirá mercado para o trabalho, os indivíduos tomarão o seu verdadeiro nível, as riquezas se tornarão legítimas, a honradez cessará de ser convencional, os elementos de ordem se fundarão sobre a liberdade, e a liberdade deixará de ser privilégio de classe.

3. Porque só com a emancipação total podem concorrer para a grande obra de uma pátria comum, forte e respeitada, os membros todos da comunhão que atualmente se acham em conflito com os outros, ou consigo mesmo: os escravos os quais estão fora do grêmio social; os senhores, os quais se vêem atacados como representantes de um regime condenado; os inimigos da escravidão, pela sua incompatibilidade com esta; a massa, inativa, da população, a qual é vítima desse monopólio da terra e dessa maldição do trabalho; os brasileiros em geral que ela condena a formarem, como forma, uma nação de proletários. (NABUCO, 2003, p.110-111).

Essa longa citação é elucidativa da posição de Nabuco sobre o abolicionismo. Fica evidente os elementos do liberalismo, assim como em Corvo, que caracterizava a escravidão como uma instituição funesta com capacidade de esterilizar os impulsos naturais do trabalho. A diferença é que existe em Nabuco um senso de urgência muito maior do que em Corvo, isso pode ser resultado da diferença temporal, já que no momento que Corvo escreveu a abolição já havia sido promulgada em Portugal, apesar de que ele considerava que os efeitos do escravismo ainda vigoravam. Além disso, acredito que o senso de urgência se dá porque Nabuco considerava que a escravidão estava muito mais entranhada no Brasil, já que nesse país toda a sociedade era corrompida, enquanto em Portugal do século XIX a escravidão ficava restrita as colônias.

Outra semelhança entre Corvo e Nabuco era a ideia de que a escravidão agiria como elemento brutalizador do negro, já que ela retirava a condição de sujeito do escravo e o tornava propriedade. Nabuco chega a descrever a maneira como a escravidão agiria para inferiorizar o negro. As palavras dele são as seguintes:

O escravo ainda é uma propriedade como qualquer outra, da qual o senhor dispõe como de um cavalo ou de um móvel. Nas cidades, em contato com as diversas influências civilizadoras, ele escapa de alguma forma àquela condição; mas no campo, isolado do mundo, longe da proteção do Estado, sem ser conhecido de nenhum dos agentes deste, tendo apenas o seu nome de batismo matriculado, quando o tem, no livro da coletoria local, podendo ser fechado num 


\section{Alistorias}

Revista do Corpo Discente do Programa de Pós-Graduação em História da UnB

Em TEMPO DE HISTÓRIAS | Brasília-DF | n. 36 | p. 66-80 | jan./jun. 2020.

ISSN 2316-1191

calabouço durante meses - nenhum autoridade visita esses cárceres privados ou ser açoitado todos os dias pela menor falta, ou sem falta alguma; à mercê do temperamento e do caráter do senhor, que lhe dá de esmola a roupa e alimentação que quer, sujeito a ser dado em penhor, a ser hipotecado, a ser vendido, o escravo brasileiro literalmente falando só tem de seu uma coisa - a morte.

Nem a esperança, nem a dor, nem as lágrimas o são. Por isso não há paralelo algum para esse ente infeliz, que não é uma abstração nem uma criação da fantasia dos que se compadecem dele, mas que existe em milhares e centenas de milhares de casos, cujas histórias podiam ser contadas cada uma com piores detalhes. Ninguém compete em sofrimento com esse órfão do destino, esse enjeitado da humanidade, que antes de nascer estremece sob o chicote vibrado nas costas da mãe, que não tem senão os restos do leite que esta, ocupada em amamentar outras crianças, pode salvar para o seu próprio filho, que cresce no meio da abjeção da sua classe, corrompido, desmoralizado, embrutecido pela vida da senzala, que aprende a não levantar os olhos para o senhor, a não reclamar a mínima parte do seu próprio trabalho, impedido de ter uma afeição, uma preferência, um sentimento que possa manifestar sem receio, condenado a não possuir a si mesmo inteiramente uma hora só na vida e que por fim morre sem um agradecimento daqueles para quem trabalhou tanto, deixando no mesmo cativeiro, na mesma condição, cuja eterna agonia ele conhece, a mulher, os filhos, os amigos, se os teve! (NABUCO, 2003, p.54).

Esse trecho, com destaque para o regime de violência, dá uma boa ideia do que ele estava chamando de brutalização, que era a destruição no escravizado da sua humanidade, do seu senso de individualidade e de trabalho. Todos esses elementos em um sentido tipicamente liberal. A escravidão seria responsável por criar indivíduos incompletos.

Talvez em Nabuco a influência da escravidão como entidade esterilizante seja mais forte do que em Corvo, que considerava a escravidão, mas dava um papel muito mais importante à raça, mas de forma alguma Nabuco desconsiderava a raça. Ele chegou a dizer que a raça negra não era inferior, que era parte importante da formação do povo brasileiro e que no Brasil não existia preconceito de cor, mas em outros trechos se contradiz e demonstra que também é devedor das teorias raciais, creditando a raça uma ação inferiorizante nos escravos. As palavras dele são as seguintes:

Muitas das influências da escravidão podem ser atribuídas à raça negra, ao seu desenvolvimento mental atrasado, aos seus instintos bárbaros ainda, às suas superstições grosseiras. A fusão do catolicismo, tal como o apresentava ao nosso povo o fanatismo dos missionários, com a feitiçaria africana, influência ativa e extensa nas camadas inferiores, intelectualmente falando, da nossa população, e que pela ama-de-leite, pelos contatos da escravidão doméstica, chegou até aos mais notáveis dos nossos homens; a ação de doenças africanas sobre a constituição física de parte do nosso povo; a corrupção da língua, das maneiras sociais, da educação e outros tantos efeitos resultantes do cruzamento com uma raça num período mais atrasado de desenvolvimento; podem ser consideradas isoladamente do cativeiro. Mas, ainda mesmo no que seja mais característico dos africanos importados, pode afirmar-se que, introduzidos no Brasil, em um período no qual não se desse o fanatismo religioso, a cobiça, independente das leis, a escassez da população aclimada, e sobretudo a escravidão, doméstica e 
Revista do Corpo Discente do Programa de Pós-Graduação em História da UnB

Em TEMPO DE HISTÓRIAS | Brasília-DF | n. 36 | p. 66-80 | jan./jun. 2020.

ISSN 2316-1191

pessoal, o cruzamento entre brancos e negros não teria sido acompanhado do abastardamento da raça mais adiantada pela mais atrasada, mas de gradual elevação da última (NABUCO, 2003, p.132-133)

Como se pode ver nessa citação, a raça é sim relevante para Nabuco, mas foram as condições do cativeiro que brutalizaram ainda mais os negros. Pior ainda foi a ação da miscigenação no Brasil. O resultado da união do negro, que era suprimido da sua força vital, e do branco, com seu ideal de senhor de escravos carregado de crimes atrozes, foi uma hereditariedade cruel e ávida de lucros ilícitos. Em outras palavras, Nabuco acreditava que a miscigenação sob o regime escravocrata foi responsável por rebaixar a raça europeia. Apesar disso, o problema não era a miscigenação em si, mas sim as condições degradantes em que ela foi feita. A miscigenação era, na realidade, entendida por Nabuco como ponto principal do seu projeto abolicionista.

Assim como os efeitos da escravidão transcendiam os escravos, a abolição também era entendida em sentido lato. Para Nabuco os efeitos da escravidão no Brasil durariam por muitos séculos, dessa forma o movimento abolicionista também não deveria acabar com a emancipação. A obra só estaria completa quando o ideal senhorial das elites econômicas do país e a brutalização dos escravos fossem exterminados. Nabuco escreve da seguinte forma:

O processo natural pelo qual a escravidão fossilizou nos seus moldes a exuberante vitalidade do nosso povo durante todo o período de crescimento, e enquanto a nação não tiver consciência de que lhe é indispensável adaptar à liberdade cada um dos aparelhos do seu organismo de que a escravidão se apropriou, a obra desta irá por diante, mesmo quando não haja mais escravos. (NABUCO, 2003, P.26).

Para Nabuco o abolicionismo serviria com um remédio para o Brasil. Uma cura que não se tratava de algo imediato e nem eliminaria apenas uma forma de trabalho, pois seria responsável pela refundação da sociedade brasileira. Dessa forma, o abolicionismo não destruiria apenas o escravo, mas destruiria também o senhor e, principalmente, seu ideal escravista atrofiador. Juntos, senhor e escravos, seriam eliminados para a construção de algo novo. Esse discurso, que à primeira vista até pode se parecer um tanto quanto fanoniano, ${ }^{3}$ também carregava um ideal de morte, que aparece no projeto de embranquecimento da população e consequente eliminação dos negros pela miscigenação.

Nabuco acreditava que não seria qualquer miscigenação que salvaria o Brasil, seria necessário um elemento com sangue vivaz, não corrompido, um sangue puro, ou seja, europeu, e as corretas condições de sociedade para a elevação gradual das raças brasileira e, por fim, sua completa assimilação. Por esse motivo, Nabuco chega a se colocar contra a inserção de trabalhadores chineses no Brasil, um projeto que foi muito

\footnotetext{
${ }^{3}$ Esta menção faz referência ao autor Frantz Fanon, que elaborou sua obra entorno de um projeto político de superação da situação colonial pela eliminação do colonizador e do colonizado. Uma das referências conceituais de Fanon é Hegel, autor que escreveu sobre a superação da dialética do senhor e do escravo. Hegel, provavelmente, é uma das referências de Nabuco. Ver: FANON, Franzt. Pele negra, máscaras brancas. Salvador: EDUFBA, 2008 e HEGEL, Georg W. F. Fenomenologia do espírito. Petrópolis/Bragança Paulista: Vozes/USF, 2003.
} 
Revista do Corpo Discente do Programa de Pós-Graduação em História da UnB

Em TEMPO DE HISTóRIAS | Brasília-DF | n. 36 | p. 66-80 | jan./jun. 2020.

ISSN 2316-1191

discutido na década de 1880 como forma de compensar a emancipação dos escravos. As palavras dele foram as seguintes:

\begin{abstract}
Compare-se com o Brasil atual da escravidão o ideal de pátria que nós, abolicionistas, sustentamos: um país onde todos sejam livres; onde, atraída pela franqueza das nossas instituições e pela liberdade do nosso regime, a imigração européia traga, sem cessar, para os trópicos uma corrente de sangue caucásio vivaz, enérgico e sadio, que possamos absorver sem perigo, em vez dessa onda chinesa, com que a grande propriedade aspira a viciar e corromper ainda mais a nossa raça; um país que de alguma forma trabalhe originalmente para a obra da humanidade e para o adiantamento da América do Sul. (NABUCO, 2003, P.205).
\end{abstract}

Em outra passagem ele chega a dizer que “(...) no futuro, só uma operação nos poderá salvar - à custa da nossa identidade nacional -, isto é, a transfusão do sangue puro e oxigenado de uma raça livre." (NABUCO, 2003, P.26). Para Nabuco, a principal marca da identidade nacional brasileira seria justamente a miscigenação entre europeus, africanos e indígenas americanos, um discurso que remete aos primórdios da fundação do Instituto Histórico Geográfico Brasileiro (IHGB), ${ }^{4}$ mas que era algo que seria necessário superar em nome do projeto abolicionista.

Assim como em Corvo, não temos aqui um discurso que remete abertamente a uma política de extermínio. Nabuco não falava de assassinar ou segregar os negros, pelo contrário. Ele falava de integração social, defendia os direitos políticos e civis dos ex-escravos. O problema é que essa integração pela miscigenação seria exatamente o que levaria a um extermínio, um extermínio pela genética, prolongado e mitigado, mas ainda sim um extermínio.

\title{
Interligações colonialistas
}

Os discursos de Andrade Corvo e de Joaquim Nabuco não era o mesmo, existiam diferenças fundamentais no que diz respeito aos espaços e aos horizontes de expectativas. Apesar disso, existia algo em comum no discurso de ambos, algo que fazia com que eles convergissem em uma linha já bem estruturada de pensamento. Esse algo é a ordem que regia o pensamento de ambos dos autores, o discurso colonial. Não consegui encontrar qualquer documento que comprove que Andrade Corvo e Joaquim Nabuco se conheciam ou ainda que tenham frequentado os mesmos espaços. De qualquer forma, isso não é tão importante para explicar as semelhanças de pensamento entre eles, já que o compartilhamento de uma base epistemológica independe de encontros físicos.

O discurso colonial reúne uma série de saberes dentro da sua estrutura, conhecimentos que ajudaram a legitimar sua visão de mundo. dentre eles está o liberalismo econômico de origem inglesa, influência clara nos dois autores. O liberalismo levou Nabuco e Corvo a tomar a cultura europeia como o ideal de sociedade

\footnotetext{
${ }^{4}$ Sobre o tema ver: MARTIUS, Carl Friedrich Phillip von. "Como se deve escrever a história do Brasil". Revista do Instituto Histórico e Geográfico Brasileiro, 6 (24), jan. 1845, pp. 389-411.
} 
Revista do Corpo Discente do Programa de Pós-Graduação em História da UnB

Em TEMPO DE HISTÓRIAS | Brasília-DF | n. 36 | p. 66-80 | jan./jun. 2020.

ISSN 2316-1191

e qualquer outro povo que apresentasse manifestações culturais diferentes era considerado incompleto. No núcleo do pensamento dos autores estava clara a ideia de que as populações europeias brancas eram a norma ou a civilização, e que todos os outros grupos seriam desvios passíveis de conserto. Esse discurso era o que justificava a colonização como "missão civilizadora" e dava legitimidade política para ela.

Ao longo do século XIX foram aparecendo novos conhecimentos devedores do colonialismo. Teorias que determinavam que algumas populações seriam impossíveis de serem "consertadas" começaram a ganhar bastante espaço político. Esse conjunto de ideias diversas ficou conhecido como teorias raciais, que em comum carregavam um caráter científico e buscavam legitimar a ideia de superioridade biológica dos brancos europeus sobre os outros grupos humanos. Elas também foram apropriadas pelos autores que aqui estamos estudando para legitimar seus projetos de necropolítica. Através das teorias raciais foi possível dar um passo definitivo em direção à morte, já que se passou a entender como natural a eliminação de indivíduos e de grupos inteiros. Algo que seria até requisito para se construir a sociedade considerada ideal.

Nesse contexto, a necropolítica, que é o que procurei focar nesse artigo, é só mais uma perversa engrenagem do sistema do colonialismo. Não surgiu do nada a ideia de que alguns grupos pudessem ser simplesmente extintos, como aparece em Corvo. Um projeto de embranquecimento da população, como sugere Nabuco, também não surge como uma epifania do autor. Pelo contrário, tais ideias foram gestadas ao longo de séculos pelo discurso colonial europeu.

O que surpreende é a projeção de tais ideias do discurso colonial. Se por um lado temos Andrade Corvo, um político de um país periférico da Europa, mas ainda sim um legítimo colonialista, não só por ideias, mas também por posição. Por outro temos Joaquim Nabuco, um intelectual de uma ex-colônia que também emula ideias colonialistas, projetando ideais de civilização típicas de países colonizadores para o Brasil. Isso demonstra que o discurso colonial não ficava restrito à Europa e muito menos aos países centrais desse continente.

Também podemos chegar à conclusão de que o abolicionismo era um projeto colonial. O abolicionismo em Portugal e no Brasil teve uma importante participação de elites intelectuais. Essas elites também estavam afundadas no colonialismo durante o século XIX de maneira comercial e material, mas, principalmente, de maneira ideológica. As duas coisas, discurso colonial e abolição, só podiam se converter em algo único. Corvo acreditava que a abolição era fundamental para viabilizar economicamente a colonização na África. Nabuco também acreditava que a abolição era a única maneira de salvar o Brasil da ruina completa e usa noções do discurso colonial, como as teorias raciais, para justificar o seu projeto. Ambos, de maneira diferente, convergem para uma política de morte, outro traço indissociável do discurso colonial do século XIX. 
Revista do Corpo Discente do Programa de Pós-Graduação em História da UnB

EM TEMPO DE HISTÓRIAS | Brasília-DF | n. 36 | p. 66-80 | jan./jun. 2020.

ISSN 2316-1191

\section{Conclusão}

Após tudo que foi dito, gostaria de esclarecer que Andrade Corvo e Joaquim Nabuco não detinham a soberania do necropoder de maneira individual. Os cargos que ocupavam e a influência que detinham nas suas sociedades, apesar de importantes, não eram suficientes para ditar quem vive e quem morre. Eles eram, na realidade, parte da engrenagem do colonialismo, essa sim, que por sua própria natureza exercia o necropoder.

O discurso colonial prega a morte. Em alguns momentos o projeto de morte do colonialismo aparece de maneira descarada, falando abertamente sobre o extermínio de populações inteiras. Outras vezes aparece de maneira mais discreta, nesse caso a política de morte está mais relacionado ao ato de criar condições para que a morte aconteça. Nesse último caso que se enquadra Corvo e Nabuco, os dois falavam de um projeto de civilização fortemente atrelado a ideais liberais, mas a idealização de sociedade construída por eles não era para todos, alguns grupos deveriam simplesmente desaparecer. A destruição de culturas também estava presente de maneira muito contundente nos dois autores, mas aqui estamos falando de um projeto de eliminação física de sujeitos. Em Corvo eram alguns grupos africanos considerados por ele como mais atrasados e em Nabuco se tratava de um apagamento da descendência negra por meio da miscigenação.

O discurso colonial só existe enquanto necropoder. As vezes o colonialismo assume novas roupagens e se une a novas bandeiras, como o abolicionismo, mas ainda assim não deixa de ser uma necropolítica. Pode parecer paradoxal que um discurso abolicionista que vai contra uma soberania de biopoder tão cruel e evidente, que é a escravidão, também se baseie em um biopoder, que é a necropolítica. Isso acontece porque o abolicionismo foi apropriado pelo discurso colonial, como uma forma de reformulação frente ao novo paradigma liberal do século XIX, então o abolicionismo acabou sendo contaminado pela necropolítica.

Para finalizar, gostaria de esclarecer que longe de serem visionários ou heróis, os abolicionistas eram pessoas do seu tempo e usavam as ferramentas epistemológicas disponíveis na época para decifrar o mundo. O discurso colonial e os seus subprodutos, como as teorias raciais e a própria ideia de civilização, exercia uma grande força no período, inclusive em Andrade Corvo e Joaquim Nabuco, o que fez com que eles construíssem um projeto de "regeneração social" que se baseava, entre outras coisas, na relação do abolicionismo com a necropolítica.

\section{Referências}

AZEVEDO, C. M. M. de. Quem Precisa de São Nabuco? Estudos Afro-Asiáticos, Ano $23, \mathrm{n}^{\circ} .1$, pp. 85-97, 2001.

CORVO, João de Andrade. Estudos sobre as províncias ultramarinas. Lisboa: Typographia da cademia Real das Sciencias. 1883 -1887. 4 vols. 
Revista do Corpo Discente do Programa de Pós-Graduação em História da UnB

Em TEMPO DE HISTÓRIAS | Brasília-DF | n. 36 | p. 66-80 | jan./jun. 2020.

ISSN 2316-1191

DAVIS, David Brion. O problema da escravidão na cultura ocidental. Rio de Janeiro: Civilização Brasileira, 2001.

FOUCAULT, M. Arqueologia do saber. Petrópolis: Vozes, 1971.

MBEMBE, Achille. Necropolítica. São Paulo: N-1 edições, 2018.

MUDIMBE, Valentin-Yves. A invenção de África: gnose, filosofia e a ordem do conhecimento. Luanda, Mangualde (Portugal): Edições Mulemba, Edições Pedago, 2013.

NABUCO, Joaquim. O Abolicionismo. Brasília: Senado Federal, Conselho Editorial, 2003.

PARRON, Tâmis. A política da escravidão na Era da Liberdade: Estados Unidos, Brasil e Cuba, 1787-1846. Tese de Doutorado: FFLCH-USP, 2015.

SAID, Edward W. Orientalismo: O Oriente como invenção do Ocidente. São Paulo: Companhia de Bolso, 2016.

YOUSSEF, Alain El. O Império do Brasil na segunda era da abolição (1861-1880).

Tese de Doutorado: FFLCH-USP, 2019. 